\title{
Climate-smart agriculture vs. agroecology to mitigate GHG emissions in Argentinean Agriculture: a false dichotomy
}

\section{Opinion}

A recent ranking about greenhouse gases (GHG) emissions elaborated by the Climate Action Tracker ${ }^{1}$ has given Argentina the rank of "highly insufficient commitment", in spite of the country reduced its intended National Determined Contribution (NDC) from 570 to $483 \mathrm{MtCO}_{2} \mathrm{e}$ to be achieved by $2030 ;^{2}$ besides, there has been a governmental effort to estimate GHG emissions at national level, resulting in a new release of the National GHG Inventory (2017), which had not been updated since 2000. The latest GHG inventory is revealing because, even though energy sector has the largest share for GHG emissions at national level (53\%), contributions from agriculture are still considerable $(39 \%))^{3}$ This highlights the need to account with agriculture capable to satisfy the growing food demand but also to be environmentally neutral through a sustainable use of soil, and minimization of GHG emissions. ${ }^{4}$ In that regard, worldwide agronomists, soil scientists and environmentalists have long conveyed their concerns through elaborated definitions and assessments, ${ }^{5}$ which can be summarized in two apparently opposite visions: climate-smart agriculture $^{6}$ and agroecology. ${ }^{7}$ In this article, it is suggested that both visions of agriculture have points in common; however, the farm scale may define the suitability of either approach, particularly in the Argentinean context.

Climate-smart agriculture (CSA) is a concept relatively new; however, CSA has been intuitively applied by argentine farmers since they are open to technology and research advances. According to FAO 's ${ }^{8}$ latest definition, "CSA is an approach that helps to guide actions needed to transform and reorient agricultural systems to effectively support development and ensure food security in a changing climate", , based on three pillars:

i. A sustainable increase of agricultural productivity and incomes;

ii. Adapting and building resilience to climate change; and

iii. Reducing and/or removing greenhouse gas emissions. Some agricultural techniques applied in the Argentinean farms such as no-till, crop rotation and precise fertilization are considered by CSA, although they differ in the degree of adoption, with no-till having the highest level.

Also, the use of biofertilizers such as manure or biochar (both of them not widespread in extensive crops), and precise application of plaguicides may be among the practices considered climate-smart, since they lead to energy savings. ${ }^{9}$ However, in spite of its worldwide recognition, the concept of CSA has not yet been wide spread as such in Argentina; instead, sustainable intensification has been used as paradigm to mitigate GHG emissions and attaining sustainability, where intensification is thought from a temporal point of view, which implies that soil must be covered all year with crops, pastures or cover crops, to keep soil health and functionality. ${ }^{10}$ Nevertheless, sustainable intensification can be interpreted as an oxymoron, ${ }^{5}$ so that its application is still under discussion in Argentina. Similarly to agroecology, CSA embraces multidisciplinary within the "hard
Volume 3 Issue 4 - 2018

\author{
Cambareri GS \\ Balcarce Research Station, INTA (Instituto Nacional de \\ Tecnologia Agropecuaria), Argentina
}

Correspondence: Cambareri GS, Balcarce Research Station, INTA (Instituto Nacional de Tecnologia Agropecuaria), Km 73.5 RN 226, Balcarce, Buenos Aires, Argentina,

Email cambareri.gustavo@inta.gob.ar

Received: May 17, 2018 | Published: July 09, 2018

sciences" such as agronomy, soil sciences and environmental sciences, and although does not exclude social sciences, its pillars are further focused on a de-ideologized framework, which has resulted in many criticisms. ${ }^{11,12}$ Despite this, CSA seems to be an interesting and more convincing framework for the mid and large scale farmers of Argentina, since some studies have shown its potential for technology innovations. ${ }^{13,14}$

Unlike CSA, agroecology has evolved from recommendations for small scale agriculture in the $80 \mathrm{~s},{ }^{15}$ to suggestions for attaining the sustainability of large farms, and even of the whole food system. ${ }^{7}$ Then, it is difficult to find only one definition of agroecology since its meaning has changed with time, and even though initially it was defined as an environment-friendly way to perform agriculture, ${ }^{16}$ the sociologic bias has completely taken hold of the concept, at the point of seeing agroecology as a way of social empowerment, giving the concept more a political than a technical dimension. ${ }^{17}$ Regardless the criticism as practice, agroecology has been soundly consolidated as scientific discipline. ${ }^{7}$ Agroecology understood as a practice (AEP) has been broadly spread in Argentina, though its adoption is resisted by large scale farmers and some academics, precisely due to that they perceive the concept as strongly ideologized and politically biased. This resistance may be also enhanced by the fact that in the narrative of AEP, there is a trend to fall into the Moore's "naturalistic fallacy"18 where food agro-ecologically produced is judged as inherently good, while food produced in a conventional way are negatively judged by AEP supporters, regardless of the nutritional quality. There is also an issue with conceptual boundaries. On one hand, there have always been fuzzy boundaries between AEP and agronomy, since the first definition of AEP arose from applying ecological principles in agriculture, ${ }^{7}$ in spite of agronomy is already based on plant population ecology to design agricultural management practices and strategies, ${ }^{19}$ so redundancy cannot be avoided. On the other hand, the boundary between AEP and organic production seem to be also fuzzy. ${ }^{20}$ In either case, AEP should to lead to a minimization in the use of external inputs for agriculture to be consistent with its original definition; ${ }^{16}$ although input minimization per se cannot be attributed with GHG mitigation whereas AEP alone cannot be considered as a replacement for agronomic strategies. 
Although Argentina contributes only with $2 \%$ to global agricultural GHG emissions, ${ }^{21}$ there is an increasing awareness about the matter, since studies about emissions have deepened during the last five years. According the last GHG inventory, ${ }^{3}$ both residues management and use of synthetic fertilizers contributes with 6.9 and $4.2 \%$ to national agricultural GHG emissions, respectively and, although these values are low compared with the contribution of land use change (16.1\%) and rangelands $(21.1 \%)$, it must be considered that there is an interannual variability of climatic and economic stressors for agriculture, likely modifying these relative contributions. For example, it is well known that Argentinean agriculture has undergone a process of extensification driven mainly by the massive adoption of no-till farming relying on summer crops; ${ }^{10}$ however, recent flood-drought cycles whereas commodities prices changes have risen the expectation for a larger area planted with winter cereals for the growing season 2018/2019. ${ }^{22}$ On one hand, this change remarks the need of studies that consider monitoring GHG also during winter months to improve the reliability of the data and the estimation of the emission factors. ${ }^{23}$ On the other hand, there is an opportunity to re-define the attributes of both CSA and AEP, through assessments that change or confirm local stakeholder's perception. Strategies for mitigating GHG emissions must be the result of a thoroughly understanding of environmental biophysics, biochemical cycles and crop management practices. This holistic approach is expected to improve both soil health and soil "climate-smartness". ${ }^{24}$ Co-existence between CSA and AEP has been suggested, stating "smartness" as defined according to scale (local or regional), and biophysical / socio-economic contexts. ${ }^{6}$ Thus, what is considered smart from AEP point of view for small paddocks (e.g. mechanical weed control), may not be that smart for large paddocks and had to be replaced by CSA techniques such as precise application of herbicides; however, both practices may contribute to build climatic resilience from a regional perspective. For that, considering the heterogeneity of Argentinean farms, a vision of CSA and AEP as complementary approaches may work for decreasing agricultural GHG emissions and leading to environmental health farms, sustainability and food security.

\section{Acknowledgements}

None.

\section{Conflict of Interest}

The author declares there is no conflict of interest.

\section{References}

1. Climate Action Tracker. Argentina; 2018.

2. República Argentina. Primera Revisión de su Contribución Determinada a Nivel Nacional. Argentina; 2016.

3. MAy DS. Inventario de Gases de Efecto Invernadero de Argentina. Ministerio de Ambiente y Desarrollo Sustentable Argentina; 2017.

4. Tilman D, Balzer C, Hill J, et al. Global food demand and the sustainable intensification of agriculture. Proceedings of the National Academy of Sciences. 2011;108(50):20260-20264.

5. Pretty J, Bharucha ZP. Sustainable intensification in agricultural systems Anna Bot. 2014;114(8):1571-1596.
6. Lipper L, Thornton P, Campbell B. Nature Climate Change. 2014;4(12):1068-1072.

7. Wezel A, Soldat V. A quantitative and qualitative historical analysis of the scientific discipline of agroecology. International journal of agricultural sustainability. 2009;7(1):01-16.

8. Food and Agriculture Organization (FAO). Climate-Smart Agriculture. Argentina; 2018.

9. World Bank, CIAT; CATIE. Climate-Smart Agriculture in Argentina. CSA Country Profiles for Latin America Series. 2nd ed. Washington D.C, The World Bank Group. Argentina; 2015.

10. Caviglia O, Andrade F. Sustainable intensification of agriculture in the Argentinean Pampas: capture and use efficiency of environmental resources. Am J Plant Sci Biotechnol. 2010;3(2010):1-8.

11. Pimbert M. Agroecology as an Alternative Vision to Conventional Development and Climate-smart Agriculture. Development. 2015;58(23): $286-298$

12. Taylor M. Climate Smart Agriculture: What is it Good For?. The Journal of Peasant Studies. 2017;45(1):89-107.

13. Long T, Blok V, Coninx I. Barriers to the adoption and diffusion of technological innovations for climate-smart agriculture in Europe: evidence from the Netherlands, France, Switzerland and Italy. Journal of Cleaner Production. 2016;112(1):9-21.

14. Khatri-Chhetri A, Aggarwal $\mathrm{P}$, Joshi $\mathrm{P}$, et al. Farmers' prioritization of climate-smart agriculture technologies. Agricultural systems. 2017;151:184-191.

15. Altieri MA, Anderson MK. An ecological basis for the development of alternative agricultural systems for small farmers in the Third World. American Journal of Alternative Agriculture. 1986;1(1):30-38.

16. Altieri MA. Agroecology: A new research and development paradigm for world agriculture. Agriculture Ecosystems \& Environment. 1989;27(14):37-46.

17. Casadinho J. La agroecología: bases cientificas, historia local y estrategias productivas en la construcción de un espacio de desarrollo integral, ético y humano. Argentina; 2015;13-31.

18. Begum H. Moore on goodness and the naturalistic fallacy. Australasian Journal of Philosophy. 1979;57(3):251-265.

19. Andrade F. Analysis of growth and yield of maize, sunflower and soybean grown at Balcarce, Argentina. Field Crops Research. 1995;41(1):1-12.

20. Bellon S, Lamine C Olivier, Abreu G, et al. The relationships between organic farming and agroecology. 2011;1-4.

21. Maraseni TN, Qu J. An international comparison of agricultural nitrous oxide emissions. Journal of Cleaner Production. 2016;135:1256-1266.

22. Bolsa de Comercio de Rosario. Guía Estratégica para el Agro. Argentina; 2018.

23. Cambareri G. Environmental Challenges to Adopt Climate-Smart Agriculture for Cereals Cultivated in the South Eastern Pampas of Argentina. MOJ Ecology \& Environmental Sciences. 2017;1-3.

24. Paustian K, Lehmann J, Ogle S, et al. Climate-smart soils. Nature. 2016;532(7597):49. 